\title{
ACHEH: THE CASE FOR POLITICAL INTEGRATION
}

\author{
Lukman Thaib
}

\section{Introduction}

The problems of political integration which make up the subject of this paper have a general relevance to the recently decolonized states of the world. Indonesia is a geographic expression, a product of Dutch colonization bringing together more than 13,000 islands with disparate histories, civilizations, cultures and also languages, and its contemporary territorial forms has been a product imposed by colonial governments, as Dr. Henry Kissinger, the former US secretary of state, had correctly written: "Indonesia was nothing but a geographic expression until the Dutch found out it was more efficient to unite the islands of Indies under a single administration."1 This was the genesis of the "Indonesian nation". Legitimacy, drawn from western ideas about self-determination, served to influence the mainstream of nationalism in Asia but at the same time also inspired sub-national sentiments among ethnic minorities.

Political scientists have regarded that a sustaining identity on the part of ethnic minorities is perceived as a deviant political culture which strikes at the very roots of national existence, its perpetuation representing a challenge to the solidarity which is fundamental to the nationalist idea. Although there is no automatic connection between minority ethnic identity and the obstruction of a political integration, 
if the cultural character of the new state is promoted in such a way as to indicate that there is no place other than for the major ethnic group and those willing to assimilate its values, ethnic estrangement is to be expected. Where nationalist success becomes equated with majority dominance then political alienation will follow and the prospect for integration will be obstructed as ethnic particularism is reinforced through the actions of those who seek, to deny it. Such an experience has not been uncommon in the region of Southeast Asia.

The ethnic community has long been a socio-cultural pattern for human organization and communication. It holds in common a set of traditions not shared by others. Such traditions included common language or myth of descent or place of origin, distinct cultural practices, and a sense of historical continuity. These primordial ties produce a strong sense of ethnic identity and solidarity and pave the way for the emergence of ethnic nationalism.

A question remains as to whether the emergence of independence movements such as: the Acheh/Sumatra National Liberation Front (ASNLF), the Republic of South Moluccas (RMS), and the Independent of West Papua (OPM) was primarily attributable to economic exploitation, as suggested by some writers, or whether it was mainly a response to cultural subjugation. Relative economic deprivation has been an element of the situation of ethnic minority communities in Southeast Asia, but what seems to be at issue primarily is a conflict of cultures which is seen as the continuation of centuries of confrontation between the indigenous and 'foreign' people.

No multi-ethnic state has proven to the surge of ethnicity, and no government of a multi-ethnic state has found the solution to the problem faced by the demands for modernization on the one hand and the tendencies of growing ethnic nationalism on the other. Determined to prevent secession and to achieve national integration,
many governments tend to resist independence movements with coercive methods, while simultaneously promoting assimilation. Such policies have proved remarkably unsuccessful.

Thus, while Jakarta considers political and economic autonomy for the ethnic minority communities to be a threat to national territory integrity, the Achehnese, Papuans, Timorese and Ambonese regard the concept of "self-determination" through referendum or direct ballot as a fundamental right of every people, believing that 'every peoples has the right to choose the sovereignty under which they
shall live'. 


\section{Political History of Nanggroe Acheh Darussalam}

Nanggroe Acheh Darussalam is one of the oldest independent nations in Southeast Asian history and according to modern Indonesian history: "Acheh was emerging as a major power, the most powerful, wealthy and cultivated state of the area ."2 At present Acheh's population is 4 million and the population of Sumatra island is approximately 25 million. Here flourished the once powerful Sultanate of Acheh Darussalam (House of Peace) as the leading state in Southeast Asia can be traced to the Portuguese capture of Malacca in 1511, which had been the dominant trading center in the region. Forced out of Malacca, Arab, Turky, and Indian merchants moved to Acheh, where they carried on barter trade primarily with Chinese merchants in search of pepper. By the middle of the sixteenth century the Sultanate of Acheh was the center of Middle Eastern and Indian trade with Southeast Asia, and by the end of the sixteenth century various Europeans merchants were competing to trade with the state of Acheh as well. ${ }^{3}$ Due to that reason Acheh's history is told largely in terms of trade. During the first half of the seventeenth century, the Acheh Sultanate was one of the most powerful trading states in Southeast Asia. A French traveller of the period provided an apt observation: "all people in the Indias or on the other sides of the Cape of Good Hope, when they would go to Sumatra, merely say they are going to Acheh, for the city and port has acquired all the names and reputation of the island." 4

The power of the Sultanate of Acheh Darussaalam attained its political greatness both internally and externally in the early seventeenth century under the brilliant leadership of Sultan Iskandar Muda (1607-1636 A.D.). It was said that in that period Royal control was effective for both domestic and foreign traders over all the important ports of the west coast of Sumatra as well as the east coast of the Malayan Peninsular. ${ }^{5}$ La Grant Encyclopedie (Paris, 1874) states: "In 1582, the Achehnese had already extended their preponderance over the island of the Sundas, over one part of the Malay Peninsula, and had relations with all the nations trafficking the Indian Ocean from Japan to Arabia. The history of the long struggle which the Achehnese people. In 1586, one of their Sultans attacked the Portuguese in Malacca with an armada of 500 warships and 60,000 marines." ${ }^{\prime 6}$

Three hundred years after the Dutch occupied Java, AchehSumatra was still an internationally recognized independent sovereign state with diplomatic and treaty relations with the rest of the world, including Great Britain.? 
However, on March 26, 1873, after three centuries colonizing Jakarta, the Dutch issued a formal declaration of war against the independent state of Acheh, ${ }^{8}$ thus acknowledging Acheh's status as an independent sovereign state. The world reacted with universal declarations of neutrality, including those from the United States (US), Great Britain, France, Italy, Austro-Hungary and many others. These declarations of neutrality also underlined Acheh's status as an internationally recognized independent sovereign state. ${ }^{y}$ The American President at the time, General Ulysses S. Grant, rejected Holland's request for the U.S. to take the Dutch side in the conflict. Instead Washington issued an official and formal proclamation of 'Impartial Neutrality' in the war between the Kingdom of the Netherlands and the Kingdom of Acheh Darussalam. Meanwhile the Ottoman Empire expressed solidarity with Acheh with preparation made for possible Turkish intervention on the Achehnese side. All this constituted sufficient proof of Acheh's status as a bona fide independent sovereign state that was universally recognized among nations.

One of the most significant events in Acheh's history came in 1824 with the signing of the London Treaty (also referred to as the Anglo-Dutch Treaty). Through this instrument, the Dutch gained control of all British possessions on the island of Sumatra (including Acheh,). In exchange, the Dutch surrendered their possessions in India and withdrew all claims in Singapore. ${ }^{10}$ In the same treaty, however, the Dutch agreed to allow independence for Acheh. Nevertheless, in 1871, the British authorized the Dutch to invade Acheh, possibly to prevent French annexation." As one writer explains it: "The situation was rather confused, with the Netherlands asserting a general sphere of influence over the entire archipelago yet formally acknowledging the independence of 'native states in amity with the Netherlands government' $\ldots$. From the mid- $19^{\text {th }}$ century, and especially after 1870 , the colonial state began to fill out the territorial boundaries of modern Indonesia by conquering or incorporating these independent states." ${ }^{\prime 12}$

Thus, in 1873 the Netherlands issued a formal declaration of war and invaded Nanggroe Acheh Darussalam. They found gaining control of the territory more difficult than expected. The Achehnese resisted occupation, touching off the Acheh War, which lasted intermittently from 1873 to 1942 . The war was the longest ever fought by the Dutch, costing them more than 10,000 lives. ${ }^{13}$ Although sources differ as to when the war actually ended (some say 1903), ${ }^{14}$ it appears that guerrilla activity continued until at least 1914 and that the Dutch did not abandon their occupation of Acheh until 1942, shortly before the Japanese invaded Indonesia. ${ }^{15}$ After their attack on Pearl Harbor, the Japanese turned South to conquer several Southeast Asian 
countries, including Singapore. The colonial army in the Dutch East Indies surrendered in March 1942. In August 1945, just days after the Japanese surrendered to the Allies, the Republic of Indonesia proclaimed its independence. ${ }^{16}$ Soon, however, both the British and Dutch were back in the region but not to Nanggroe Acheh Darussalam, for various political and economic reasons.

The next major development was the 'Linggarjati Agreement', mediated by Great Britain and signed by Indonesia and the Netherlands in March 1947. In the agreement, the Dutch recognized Indonesian sovereignty over the islands of Java, Sumatra, and Madura. However, many Indonesians viewed the deal as 'a violation of Indonesia's independence proclamation of August 1945, which implied sovereignty over the whole territory of the Republic'. ${ }^{17}$ The agreement sparked more guerilla fighting and led to another four years of violence and territorial disputes between the Netherlands and Indonesia.

Perhaps the most critical event in explaining the attitude of many Achehnese is the signing of the 1949 Round Table Conference Agreements. ${ }^{18}$ Brokered under the auspices of the United Nations, the agreements provided for a transfer of sovereignty between the territory of the Dutch East Indies and a fully independent Indonesia. On December 27,1949, the Dutch East Indies ceased to exist and became the sovereign Federal Republic of Indonesia, which in 1950 once again became the Republic of Indonesia when it joined the United Nations. The Kingdom of Acheh was included in the agreements despite not having been formally incorporated into the Dutch colonial possession. ${ }^{19}$ Subsequently, the Java-based Indonesian government used armed troops to annex Acheh/Sumatra. Since annexation, the Achehnese have continued to resent what they consider foreign occupation.

\section{The Free Acheh Movement}

The precursor to Acheh's independence movement began in the 1950s when Indonesia experienced the Darul Islam rebellion, in which rebels on the major Indonesian island of Java tried to establish an Islamic state. The Achehnese lent support to this rebellion, which took years to crush. In 1959, the government responded by giving Acheh the status of "special territory", which ostensibly confers an unusually high degree of autonomy in religious, educational, and cultural matters. ${ }^{20}$ Although many Achehnese say the status is virtually meaningless, other observers say it led to greater prosperity and helped bring Acheh into the Indonesian mainstream. ${ }^{21}$ 


\section{The Emergence of Acheh/Sumatra National Liberation Front (ASNLF)}

Despite some economic improvements and acceptance by some Achehnese of the Indonesian government, the desire for 'an independent democratic state' did not die. In December 4, 1976 through a 'Redeclaration of Independence' in the spirit of the American declaration of Independence, the Acheh/Sumatra National Liberation Front (ASNLF) was founded. ${ }^{22}$ The movement is headed by Dr. Tengku Hasan Muhammad di Tiro, who has been in exile in Sweden since 1980.

The reason for issuing the "Redeclaration of Independence" according to Tengku Hasan di Tiro is only to serve as a notice of its commencement, and a preparatory stage to a future struggle. ${ }^{23}$ When the Achehnese have properly grasped the meaning and the purpose of their 'redeclaration of independence' by obtaining political consciousness then no Indonesian colonialist regime can prevent them from gaining that independence.

Another reason was to combat sinister Javanese/Indonesian colonialist propaganda abroad to label the Achehnese as "Muslim fundamentalist" which was aimed at establishing an Islamic state, or to call them "terrorist" and "separatist". The Achehnese are aware that they cannot have moral, political, and military support before they first legitimized their struggle politically as a national liberation movement by bringing their case to the Decolonization Commission of the United Nations. ${ }^{24}$ No party in the world will help a fundamentalist, a terrorist, or a separatist movement. That is why the Indonesian regime is trying to label the Achehnese as 'fundamentalist', 'terrorist', or 'separatist' so that they cannot get sympathy from the outside world. But the international community will give sympathy and moral support to the legitimate national liberation movement and the legitimate independence movement such as theirs. For 125 years to date, the people of Acheh have been continuously bled under foreign invaders of all colours, white, yellow and brown, of all religions, Christians, Buddhists and Muslims. Each of these alien aggressions had fabricated their own colourful justifications for invading Acheh Darussalam and killing the Achehnese. For the Dutch it was to 'suppress piracy and to bring civilization', for the Japanese it was 'to bring East Asian Great Prosperity', and now for Javanese/ Indonesian 'to suppress Muslims Fundamentalists', shamelessly playing on the fear of western interests making astronomical profits from the enormously rich petroleum, natural gas resources and gold of Nanggroe Acheh Darussalam. 
Accusing Achehnese freedom fighters as mere 'Muslim Fundamentalists' is in order to deny them their historic political, legal, and human rights and is the height of calumny. For to inject a religious issue, especially when in fact there was none to a legitimate independence struggle is to undermine it, and to falsify it as a religious movement concerned merely with fanaticism and sterile theological disputations, unrelated to International Law, International Conventions, Human Rights principles and to the right of selfdetermination.

The questions of "Islamic state" has never been raised by the Acheh Free Movement (Acheh Merdeka), not even in its 'Redeclaration of Independence'. It was raised ironically and solely by the Indonesian military authorities in Jakarta, as a scarecrow to justify its aggression and colonization of Nanggroe Acheh Darussalam in the eyes of some of its uninformed allies. Acheh Darussalam wants to remain independent not because 'Indonesia is not an Islamic State', but because Acheh Darussalam naturally wants to keep its identity, its rights, and its historic status as an independent, free, nation. Whether Indonesia is an 'Islamic State' or not, is no concern for Acheh Merdeka.

Tengku Hasan di Tiro's Redeclaration of Independence which is regarded as the most authoritative document for freedom of Acheh Merdeka, is emphatically not religious or theological, but a political and legal matter, to re-instate their historic state that was internationally recognized as an independent sovereign state by major powers.

Thus, the emergence of the Acheh/Sumatra National Liberation Front (ASNLF) is a genuine attempt to fulfill the historic and democratic quest of the Achehnese who have been colonized under the Indonesian hegemony. From the perspective of international law and conventions, the struggle of the Achehnese is in keeping with the right of self-determination, as the United Nations affirmed:

"It is widely accepted that a group of people that is presently subjected to military occupation that traditionally has formed a nation of its own or has been a part of a different nation than the one which occupies it, is entitled to assert or to restore its self-determination." 25

Since its formation the ASNLF have withstood the worst assault by the Indonesian forces and are getting stronger by the day. The area of liberated territory has been expanded. Although the Indonesian army still occupy major cities, it has lost control of the country side where the population and loyal supporters of the liberation struggle 
are concentrated. The celebaration of twenty years of struggle on December 4, 1996 showed the ASNLF's growing strength and confidence. Nevertheless, the Indonesian regime has been making propaganda abroad to the effect that they had crushed the ASNLF and that the struggle for the liberation of Acheh has failed.

In general since its inception, the ASNLF activities can be divided into four phases. The first phase of the insurrection began a year before the 1977 general election in Indonesia had intensified friction between the Achehnese nationalists and the Indonesian authorities. Many of the 1976 generation of ASNLF activists were killed or imprisoned, while others fled the country and are now in exile in Sweden.

The second phase of insurrection began in the middle of 1989, when the ASNLF cadres came back to Acheh from Malaysia, and used several economic and political arguments to whip the young men into a state of rebellion to liberate Acheh. The eighties were used to develop a better organizational structure for ASNLF and several thousand Achehnese were trained in varying skills of guerilla warfare.

In early 1990, responding to attacks by Acheh Merdeka, the Indonesian security forces launched a counter-insurgency campaign code named "Red Net" (Jaring Merah) ${ }^{26}$ The operation led to the deaths and disappearances of many civilians, and the majority of the Achehnese believed that the army tactics went too far. The army would in discriminately round up and detain local civilians after an incident attributed to Acheh Merdeka, and families of Acheh Merdeka supporters were often arrested without legal recourse. As one Achehnese described it:

"The Indonesian military would come and accuse villagers of being involved in the liberation struggle, directly or indirectly, or being sympathizers. Sometimes they burned the villages...The army took the men for interrogation and maybe put them in prison, and sometimes the women were raped and killed in front of the other villagers. ${ }^{\prime 27}$

In 1991, Indonesia designated Acheh as a "Military Operation Area" $(D O M)$, giving the army "a free rein to crush the rebellions", as Javanese Major General Pramono, military commander of North Sumatra, admitted, many people had been killed in Acheh and that killing was occuring every day. In his own words the military commander made clear that killing people suspected of being ASNLF activities was official policy. He said: "I have told the people the important 
thing is, if you see a GPK, you should kill him. There is no need to investigate. Just shoot him or knife him. I have instructed people to carry weapons, machetes or whatever. If you see a GPK, just kill them." 28 The ASNLF reported that between 1989 and 1992 about 30,000 were killed in military operations in Acheh, ${ }^{24}$ and according to the European Parliament based on resolution no: B3-0320/91 only 5000 Achehnese were massacred within that period, ${ }^{30}$ while Independent Indonesian investigators have estimated that the number of people who were killed, missing or physically abused between 1989 and 1998 runs into the thousands, ${ }^{31}$ with more than 1,000 still in military detention. ${ }^{32}$ The human rights group FORUM, which oversees 78 non-governmental organizations in Acheh, says it has compiled 668 reports of atrocities in Acheh during the height of the military operation. Many witnessses said there were kidnapped victims who were forced to bury people whom the military had shot or tortured to death. ${ }^{33}$

The Third phase was the diplomatic affort by ASNLF which started in June 12th, 1990. As reports about mass killings began to leak out in early 1990 and the international community condemmed the massacre and pressed the Indonesian government to account fully for the killings, the President of ASNLF, Dr. Tengku Hasan Muhammad di Tiro submitted the Achehnese struggle for selfdetermination to the United Nations Special committte on decolonization. ${ }^{34}$ Based on the above request, the President of ASNLF gave his first submission at the UN Sub-Commission on Prevention of Discrimination and Protection of Minorities- $43^{\text {rd }}$ session on August $23^{\text {rd }}, 1991$ under the title: "the use of the judiciary by the Indonesian regime tosuppress the ASNLF." 35 The second submission was delivered before the $48^{\text {th }}$ session on January $29^{\text {th }}, 1992$ under the title: "the right of peoples to self-determination and its application to people under colonial or allien domination." ${ }^{36}$ With the support of sponsor governments and the nongovernmental organisations, he led the way for the first time to table a resolution on the Achehnese struggle which was considered at the annual session of the UN Sub-Commission on Prevention of Discrimination and Protection of Minorities which took place on August $17^{\text {th }}, 1993$ with proposed resolution number: E/CN2.4/Sub.2/1993/ L.21 and the second one took place on August 18 ${ }^{\text {th }}, 1994$ with proposed resolution number: E/CN.4/Sub.2/1994/L.25. ${ }^{37}$

The fourth phase started with the downfall of President Soeharto on May $21^{\text {st }}, 1998$ and sparked J.B. Habibie's promises of reforms which resulted from a mix of factors. Since the fall of Soeharto, many Achehnese have spoken out against Indonesian army (ABRI) brutality. Several mass graves have been uncovered recently, resulting in calls for the prosecution of those responsible. On August $7^{\text {th }}$, 1998, a startling 
event occurred, Indonesian military chief General Wiranto visited Acheh and issued an apology as he said: "On behalf of Indonesia's armed forces, I apologize to the people of Acheh if, during military operations, the armed forces have made you suffer." ${ }^{38}$ At the same occasion he also announced the end of Acheh's status as a "military operations region" (DOM). However, at the conference, journalist Yarmen Dinamika quoted Gen Wiranto as saying that soldiers who committed atrocities in Acheh would not be prosecuted because "they were only carrying out their duties." ${ }^{39}$ Was it their duty, Yarmen asked, to rape women, hang babies, torture and murder?

The Generaal Wiranto's announcement came on the heels of reports of "mass graves" discovered in Acheh by human rights investigators. During his visit to Acheh, Wiranto met with human rights groups planning to exhume at least nine suspected gravesites including one known as "Skulls Hill"-for evidence of human rights violations.

In late August, a team from Indonesia's official National Human Rights Commission completed its investigation of the mass grave sites. Returning to Jakarta, they announced that they dug up the remains of at least 22 bodies from multiple graves, lending support to locals' claims of mass slaughter by the military. The team said they had taken "a random sampling" and had the proof they needed. ${ }^{40}$

The Commission also released a preliminary report in which they said at least 781 people were killed during military operation in Acheh, while at least 368 were tortured, more than 102 women were raped, and 163 people were still listed as missing. ${ }^{41}$ Althought these estimates were cautious compared with those made by other human rights investigators, General Wiranto criticized the Commission for issuing the report, saying: "These findings have no legal support." He suggested that some of graves could date back to the independence battle with the Dutch in the $1940 \mathrm{~s}^{43}$ Subsequently, Wiranto released the Indonesian military's own estimates of the death toll from the Achehnese military campaign, putting the total figure at 760 people. Of those killed, 111 were soldiers, said the military. Wiranto said that 243 civilians were murdered by armed rebels, while the Jakarta Post said the military shot and killed 406 rebels. ${ }^{44}$

According to human rights investigators, most of the atrocities in Acheh were carried out by the elite Kopassus special forces under commander Prabowo Subianto, Soeharto's son-in-law, who is also accused of the abduction and torture of political activists during the civil unrest that led to resignation of President Soeharto.

The renewed violence in Acheh took place in December 28, 1998 when soldiers and police stations were attacked by mobs angered at 
lack of progress in investigation of military abuses. In the ensuring violence, seven soldiers and at least 22 civilians were reported killed, including five tortured to death by soldiers. Human rights groups report at least 42 civilians injured and 170 detained. ${ }^{45}$

In early January, 1999 news of clandestine killings of alleged informants (Cuak) and the presence of professional killer (Ninjas) from Jakarta coupled with a marked increase in military activity and an increasingly violent response from the Achehnese people through their "Sweeping Operations" and identity card searches because of the ninjas. When the Achehnese villagers stoped a bus carrying sixteen ninjas soldiers and kinnapped three of them and their bodies were later found in the Arakundo River in East Acheh.

In retaliation, on January $3^{\text {rd }}, 1999$ the army launched "Assert Authority" (Operasi Wibawa) operation to search for their men, while the villagers marched into Lhokseumawe to protest about central government indifference. The military soon began to fire indiscriminately on men, women and children in the streets of Lhokseumawe. Local estimates suggest that as many as forty people were killed in and around Lhokseumawe and 150 were arrested and dozens were treated in hospital. ${ }^{46}$ The army's response was unequivocal. In sharp contrast to its 'commitment' to resolving the thousands of cases of human rights abuses committed against civilians in Acheh, the military pulled out all the stops in the search for its personels. This included drafting in hundreds of reinforcements from Medan and Jakarta, including airborne troops and Brimob and Gegana elite police forces.

In the early morning of February $3^{\text {rd }}, 1999$ again another massacre occurred outside the local military command in the village of Idi Cut, East Acheh. Large crowds of people were returning home at a leisurely pace, some on foot, others on motorcycles or pick-uptrucks, from a gathering at the village of Matang Ulim. The event which was attended by five thousand people had proceeded peacefully and without incident. In addition to religious exhortations, the rally heard speeches about the history of Acheh Darussalam and about Free Acheh Movement, known as ASNLF (Acheh Merdeka), ${ }^{47}$ a movement that the Indonesian army has been trying to quell since the mid 1970s.

Three hours before the meeting commenced, troops attacked people who were constructing a stage and preparing the venue for the rally. They destroyed the stage, beating and injuring many people, including a three-year old boy, and told the organisers that the rally should be cancelled because no permit had been granted. However, 
thousands of people from surrounding villages were on their way already and the rally went ahead as planned.

After the crowd dispersed in the early hours of Wednesday, hundreds of people were pelted with stones by youths as they neared the local military command (Koramil) in Idi Cut, in response to which some people described by witnesses as 'troublemakers' mingling with the crowd started throwing stones. As this was happening, three army trucks drove up and without warning, opened fired from their raised vantage point, killing and wounding a large number of people. According to witnesses, gunfire continued to be heard for several hours, while blood was flowing everywhere and the area where many people lay dead, dying or wounded was sealed off by the army. The day after the massacre, it become known that some of the bodies had been taken to a bridge spanning the Arakundo River and thrown into the river. It is clear from the way the bodies were disposed of that the army had gone to great lengths to conceal the scale and the nature of the atrocitiy, to lie about the number of casualties and to shift the blame for the deaths.

The fact that thousands of people turned up to attend a rally and listen to speeches about Acheh Merdeka reveals the depth of popular feeling in Acheh and the revulsion against rule from Jakarta which has intensified since the downfall of the dictator Soeharto last May.

In the wake of this latest atrocity, there have been growing calls in Acheh for it to separate from the Republic of Indonesia by means of "a referendum", bearing in mind that the Achehnese people have experienced one tragedy after another over the past ten years while members of the armed forces enjoy impunity from prosecution. Moreover, the Achehnese people have stood by powerless as the territory's rich natural resources have been exploited for the benefit of the heavily-centralized Indonesian state and those who control the country's economy, while receiving almost nothing in return.

In response to the deepening sense of frustation in Acheh about its status and the overwhelming role of the military, an Achehnese political scientist at the Dept. of Political Science-UKM through his interview with the Indoesian 'Forum Keadilan' in January $16^{\text {th }}, 1999$ on "Alternative Solution to Acheh's Conflict", which also published by Malaysian "Massa" magazine on July 10 $10^{\text {th }}, 1999$, under title "Alternatif Penyelesaian Konflik Acheh", proposed that as the first step to resolution it is necessary for Indonesia to have a "Constitutional Reform". This was supported by Acheh's provincial governor, Professor Syamsuddin other Indonesian provinces to become part of a federated state. ${ }^{+18}$ This 
elicited a sharp rebuke from Indonesia's Minister of Justice, Professor Muladi, asserting that Indonesia is a unitary state. The Minister, however, on July $16^{\text {th }}, 1999$ issued an announcement which stated that: "The Indonesian government will set up an independent team to help end violence in the province of Acheh which will included all figures, but he ruled out the ASNLF (GAM) being a part of the team" ${ }^{49}$ From Achehnese viewpoint, to excluded the ASNLF as a part of the team to find a permanent solution to the resentment in Acheh in unacceptable. This stand is due to the role of ASNLF as "real actor" in local politic, and mojority of Achehnese has proved their loyalty to their independence movement, for that reason they successfully boycotted the Indonesian general election which was held on June 7th, 1999. What is important for Indonesian government is "to accept the fact" that due the failure of Indonesian diplomats at the United Nations maked the ASNLF successfully 'brought and registered' the Achehnese struggle for 'self-determination' at the United Nations Decolonization Commission on August $17^{\text {th }}, 1993$. This achievement of ASNLF (GAM) has also recorded by foreign observers at the world body, as foreign media reported that:

"Jakarta was clearly very concerned at the prospect of having to fight on another diplomatic front besides East Timor. As lobbying on Acheh intensified, the Director General for Political Affairs of the Indonesian Foreign Affairs Department, at the time, S. Wiryono showed up in Geneva from Jakarta to reinforce the existing Indonesian team of diplomats at the United Nations." 50

In its statement, the Indonesia Human Rights Campaign (Tapol) in London called on European Union (EU) embassies in Jakarta to dispatch a team of diplomats to Acheh to conduct investigations, consult local human rights NGO's and report back to the EU Cuncil of Ministers. It also called for an end to the army's current operation known as "Operasi Wibawa", for all special forces to be withdrawn from Acheh/Sumatra as the first step towards the total demilitarisation of Acheh.

\section{Recent Development}

The fact is that the announcement made in early August 1998 of ABRI withdrawal from Acheh which ended the Acheh's status as a "Military Operation Region" (DOM) signified that the Achehnese no longer 
accept ABRI's dominant role in society, nor are the authorities able to cope with the many social eruptions. The disturbances in Ambon, Irian Jaya and East Timor and parts of Java have exposed ABRI's weaknesses. The demand for wide-ranging autonomy, federalism or independence is growing in many of the country's farflung regions.

To accomodate the situation which is described as a potential for "rising violence" and escalation of "social unrest" and which can lead into an increasing mistrust of the central government in Jakarta, the Indonesian foreign minister, Ali Alatas on July $22^{\text {th }}, 1998$ in New York stated that: "I would like to tell you that very soon we will have a new law offering wide-ranging autonomy to all parts of Indonesia at the district level, except East Timor, which will be a special case," and in February 1999, the Indonesian government through its House of Representatives introduced the policy change which is called "Revenue Sharing Policy". This policy has changed the position of Indonesia as "one of the most centralized fiscal systems in the world, with $89 \%$ of all revenue sources flowing to Jakarta". When the bill went to Parliament for the first time in February, 1999 it made no mention of revenue from natural resources, authorizing only the "transfer of regional taxes and levies from provincial to district level" ${ }^{52}$ By early April, however, Jakarta realized it would have to offer something a lot more concrete to stave off deepening unrest and profound mistrust of the central government. The final shaped of the bill offered the resource-rich provinces with $15 \%$ of the government's share of net oil revenue, $30 \%$ of gas revenue, and $80 \%$ of income derived from forestry, mining and fisheries..$^{53}$

At the present, the existing contracts with multi-national Companies entitle the government to $85 \%$ of a contractor's gross oil revenue and $70 \%$ of gross gas revenue, none of which has ever gone to the provinces of origin. In fiscal 1997-98, oil and gas production amounted to 35.4 trillion rupiah ( $\$ 4.1$ billion), or $32.7 \%$ of total government revenues of 108.2 trillion rupiah..$^{54}$ In an effort to protect poorer provinces, the government also proposed some measures such as allocation of "block grants" to provinces amounting to at least $25 \%$ of the central government's total internal revenue. However, the provincial administrators who have been briefed on the new law say that the revenue-sharing formula applies only to onshore oil and gas. Because the autonomy legislation defines a province's boundaries as falling within five kilometers of the coastline, this could have serious implication to some provinces such as Kalimantan (Borneo), whose biggest gas field are up to 40 and 50 kilometers offshore.

Although the "April's 99 Bill" can be regarded as a gesture of goodwill of J.B. Habibie's "reform cabinet", natural resouces are not 
the only bone of contention in Indonesia's inter-state relations. This can be seen where Bali's local government has asked the central government to increase its share to more than $1 \%$ in tourism earning. Whatever the law was, one thing which is positive from an administrative viewpoint is, that the "April 99 Autonomy Bill" promised a major transformation in the district's administration. With the existing law, the election of mayors and district chiefs is consistent with a decision by the Indonesian military last October to rewrite its dual function (dwifungsi) doctrine, which gives it an institutionalized role in political life. This spells the end of the kekaryaan system, under which thousands of serving officers fill positions in the civilian bureucracy. To the majority of Achehnese the "April 99 Autonomy Bill" which provides the autonomy to district/regencies (kabupaten) all over the Indonesia would not even be as a tiny portion of the acceptable solution. For the Achehnese, it is only another "divide and rule" policy of the central government in trying to tightly control the outlying resouces rich. Is this the reform offered by the so called "Reformist Government"?

From the Achehnese viewpoint, whatever the central government afford to reduces the "social unrest" in the province, including the mentioned goodwill gesture and apologies made by General Wiranto and President J.B. Habibie, to placate the angry Achehnese has been damaged by sending the PPRM forces (PPRM is a combined high-calibre army/police unit) to Acheh, instead of reducing the existing troops from Acheh's region. The Achehnese does not believe that the PPRM forces have been sent to the region to contain mass unrest, but rather in order to contain and control every aspect of Acheh. This kind of attitude of the central government also indicates that the security approach during the J.B. Habibie regime is not so very different from how it was under the New Order.

The latest massacre which was regarded as the worst atrocity in Acheh since 1945 was called "The Dewantara Tragedy" which took place in front of P.T. Kertas Kraf Acheh- Krueng Geukuh, district of Dewantara on May $3^{\text {rd }}, 1999 .{ }^{55}$ The Incident began with a ritual ceremony in support of orphans at Cot Murong on April 30. An army intelligence with a walkie-talkie and armed with a pistol was challenged to explain his presence there. He was held for a while by angry villagers then allowed to leave, the army however alleges that he is 'missing'. While more ritual events were taking place on $1^{\text {st }}$ and $2^{\text {nd }}$ May, troops mounted are a wide searches, combing villages to find the 'missing' officer. The atmosphere grew tense as soldiers treated villagers very roughly, making their way forcibly into people's homes. Although there were assurances from local civil and military 
authorities that troops would stop pestering villagers, the operations continued and were even intensified. Medan's Waspada (a regional newspaper) in its issue of May $3^{\text {rd }}$, described the atmosphere in the area as "extremely tense" because of searches being conducted by truckloads of troops in many parts of Dewantara sub-district.

Around $10 \mathrm{am}$ on May $3^{\text {rd }}$, ten thousand people were gathered at a road junction near a factory, PT Kertas Kraf Acheh, trying to make their way to the district authorities to complain about the army's operation. While the crowds were arguing with the troops who had ordered them to disperse, a truckload of soldiers suddenly appeared. The troops got down and, without warning, opened fire on the crowd with live ammunition. They continued to fire as the crowds fled to safety, leaving many people dead and wounded. The first casualty list of 23 dead was soon overtaken. Four days after the massacre, the death toll had risen to 39 , with more than a hundred critically ill people still in hospital. Among the death were a 7 year old boy and a 12 year old girl. ${ }^{56}$ Human rights organizations believes that more than sixty people were killed as some of the dead and wounded were taken home while bodies may have been removed from the scene by the army.

Surgeons have confirmed that all the dead died from gunshot wounds and that live bullets were used, refuting army claims about rubber bullets being used. Some bullets have been kept as evidence, while local groups have collected empty bullet shells found at the site of the massacre. Medical evidence showed that many of the dead were shot as they fled. No one takes seriously army claims that AK- 45 bullet shells were found (this kind of ammunition is said to be used by ASNLF's army units but evidence that ASNLF is operating anyway is also lacking). The army claims that there was an exchange of fire with ASNLF's army and that they fired in selfdefense have been strongly denied by eye-witnesses. As usual, the army's modus operandy in Acheh however has sought to label all oposition and dissent in the region as ASNLF (GAM). But observers, including the North Acheh chief of police, concur that recent activities blamed on ASNLF by the military are in fact the work of provocateurs with an interest in destabilising the Acheh region. ${ }^{57}$ The widely held view among student activists, human rights monitors, local politicians and commentators is that these provocateurs are in the pay of the
armed forces.

In reality we can say that in the eight months since "Military Operation Region" (DOM) was lifted, there have been numerous human rights abuses and atrocities in Acheh, each one worse than the last. These atrocities have been reported in the Indonesian press and 
around the world, but the perpetrators have gone unpunished and calls for a full investigation have been ignored, while each new atrocity has deepened Acheh's political social crisis.

Indeed, the continuity of military operations in some areas of Acheh nowadays has resulted in an increase of human rights abuses and damaged the peace of the community. The coming of the Indonesian Army Forces (ABRI) in general, and PPRM forces in particular has made the Achehnese people in almost every regency run away as refugees to areas that are considered peaceful places. At present the refugees are concentrated in four districts, North Acheh 63.800 refugees, East Acheh 13.357 refugees, Pidie region 60.700 refugees, and Western Acheh around 7.500 refugees. ${ }^{58}$ The state of health among refugees in all refugees camps is beginning to cause anxiety. Disease has begun to strike because of the conditions in which the people are living and the lack of bedding to sleep on. They are sleeping on the bare ground in mosques, schools in drafty places, with inadequate food and drink, according to a local health post. This situation, however, still cannot make the ABRI realize that their actions are against human rights and democracy. The refugees are frequently intimidated and threatened by ABRI. Even, those who work for humanity and democracy such as university students, youth and boarding school students are also treated in the same way. As a result of human rights violations in Acheh by Indonesia's ABRI the Achehnese has boycotted the Indonesian general elections which has taken place on June $7^{\text {th }}, 1999$.

\section{The Expected Resolution}

It appears that killing in Acheh is still the order of the day for Indonesian $\mathrm{ABRI}$ some eight months after military operations were formally terminated. The presence of PPRM in this regency at this moment brings about fear among the people. They are more traumatised. This bitter condition is the evil of Indonesian Military for the Achehnese that continuously happens. Apparently the military is proud after intimidating and killing the Achehnese people, and they can even make a good carier out of it, and get a promotion to a high rank. On the other hand, military gets stressed and frustrated when facing Acheh/Sumatra National Liberation Front (ASNLF=GAM) army in war that still happening now. Being losers, the Indonesian Military kills the innocent Achehnese. 
Considering the escalation of the serious conflict, the following actions must be taken without delay, to halt a further deterioration in Acheh's political and social crisis:

1. With regards to human rights violations need to be done:

a. The government of Indonesia should revoke the February 1999 order from the Commander of the Armed Forces for security forces to shoot-on-sight suspected criminals and rioters.

b. The Indonesian government must take immediate steps to end unlawful killings and excessive use of force by the security forces against Achehnese people.

c. All governments should press the Indonesian government to withdraw its troop from Acheh/Sumatra as the first step towards the total demilitarization of Acheh.

d. All governments should press for an investigation by the UN Special Rapporteur on Extra-judicial, Summary or Arbitrary Executions to establish the facs and make recommendations for a radical improvement in the human rights situation in Acheh.

2. With regards to permanent political settlement, it is necessary for governments to urge Jakarta not to try to quell the referendum campaign in Acheh with violence, in the interest of freedom of expression and process of democratization in the country.

3. To affect a change in the present unitary sistem, Indonesia should accommodate a new road to freedom for the people of Acheh. The Achehnese need to be given a chance to decide their future based on ASNLF's (GAM) proposed resolutions at the Ecosoc of the United Nations no: E/CN2.4/Sub.2/1993/L.21, August 17th 1993 , as well proposed resolution no: E/CN.4/Sub.2/1994/ L. 25 in August $18^{\text {th }}, 1994$. This new road cannot be other than the road to legitimate 'Self-Determination' through democratic mechanism such as referendum r direct ballot, whether they want to be an independent state in the form of "Confederation of Acheh/Sumatra (CAS)", or in the form of "Commonwealth Independent States of Indonesia (CISI)", or whether they want to be integrated or remain as part of Indonesia in the form of "Loose Indonesian Confederation (LIC)."

The restoration of territorial sovereignty over Acheh to the Achehnese, over Sumatra to the Sumatrans, and over Javanese territory to the Javanese, is an act of justice too long denied. This is the only way to secure peace, security and harmony to this vast region hitherto 
drawn into endless anarchy, lawlessness, oppression, and injustice, caused by incessant rebellions against Javanese colonialism on one hand, and by the Javanese cruel suppression of these nationalities on the other. Through this act of justice, the most important source of conflict, that of the people of one country trying to lord it over the other shall have been made impossible. Once peace and security are restored, the road to development and progress, which has been blocked for many decades, will be wide open. The problems of administration will have been reduced to manageable size, and economic planning will be made possible and praticable. 
Notes

1 Henry Kessinger, Nuclear Weapons and Foreign Policy, Washington D.C: W.W. Norton, 1967, p. 256.

2 M.C. Ricklets, A History of Modern Indonesia, Bloomington: Indiana State University, 1981, p. 335.

${ }^{3}$ Lukman Thaib, Political Dimensions of Islam in Southeast Asia, Bangi: Dept of Political Science, UKM, 1996, p. 24.

4 Albert Gray, trans, The Voyage of Francois Pyrand to the East Indies, the Maldives, the Moluccas and Brazil, London: Hakluyt Society. vol.2, part 1, 1887-1890, p. 159.

${ }^{5}$ Lukman Thaib, The Roots of Achehnese Struggle, Bangi: Dept of Political Science-UKM, 1997, p. 11

6 Quoted from Tengku Hasan M. di Tiro, "A Memorandum on Acheh: A New Birth of Freedom", London: House of Lord, 1992, p. 5.

"Lukman Thaib, "Acheh's Case: Possible Solution to the Conflict", International Seminar on Future Integration of Indonesia: Focus on Acheh, American University, Washington D.C., April 3rd, See also, The Roots of Achehnese, 1999, p. 11.

8 "Proclamatie", taken from Suara Acheh Merdeka, London: BM Box 3294 WCIN 3XX, August 1999, p. 8.

9 Hasan di Tiro, "A Memorandum on Acheh", p. 5.

${ }^{10}$ Website for Acheh Home Page, 1998, "Historical Background of Acheh", www.aceh.org.

" Robert Cribb, Historical Dictionary of Indonesia, London: The Scarecrow Press, Inc, 1992, pp. 2-3.

${ }^{12}$ Ibid.

${ }^{13}$ Acheh Home Page, "Historical Background of Acheh".

${ }^{14}$ Cribb, Historical Dictionary, p. 3.

${ }^{15}$ Acheh Home Page, "Historical Background of Acheh".

${ }^{16}$ Ibid.

17 Website of Embassy of Indonesia for Canada, 1998, "The History of Indonesia", www.prica.org/Indonesia/general/history.html.

${ }^{18}$ U.S. Committee for Refugees, "The Least Risky Solution", Washington D.C.: US Committee for Refugees, 1998, p. 4.

${ }^{19}$ Ibid., p. 5.

${ }^{20}$ Cribb, Historical Dictionary, p. 4.

${ }^{21}$ William H. Frederick and Robert L. Worden, eds, Indonesia: A Country Study, Washingtin D.C.: Federal Research Division, Library of Congress, $5^{\text {th }}$
edition, 1993, p. 227 .

${ }^{22}$ Tengku Hasan M. di Tiro, The Price of Freedom (The Unfinished Diary), Sweden: Information Dept of ASNLF, 1981, pp. 24-27.
Ibid., pp. 28-30. 
${ }^{24}$ Tengku Hasan M. di Tiro, "First Telex to the United Nations Decolonization Commission", Sweden: Information Dept of ASNLF, June 12nd. 1990.

${ }^{25}$ United Nations, "Unesco doc 23, 1990, para 42. For more detail see Lukman Thaib, "Acheh's Case", p.6.

${ }^{26}$ Jakarta Post, "ABRI Begins Pulling out Combat Troops from Aceh", Jakarta, August, 21th, 1998.

${ }^{27}$ US Committee, "The Least Risky", p.7.

${ }^{28}$ Lukman Thaib, "The Arms Conflict in Acheh/Sumatra and Its Security Impact on Southeast Asia", International Seminar, FSKK-UKM, BangiSelangor, August, 1998. See also, TEMPO Magazine, Jakarta: November, 17 th, 1990.

${ }^{29}$ Lukman Thaib, The Politics and Governments of Southeast Asia, Kuala Lumpur: Golden Books Center Sdn Bhd., 1997, p. 35.

${ }^{30}$ Ibid., p. 54.

${ }^{31}$ Jakarta Post, "The Aceh Killing Fields", Jakarta: August 6th, 1998.

${ }^{32}$ Jakarta Post, "ABRI to Withdraw Troops from Aceh", Jakarta: August 8th, 1998.

${ }^{33}$ Agence France Presse, "Indonesia to Withdraw Troops from Aceh as Mass Graves to be Dug Up", Paris: July 8th, 1998.

${ }^{34}$ Thaib, The Politics and Governments, p. 53.

${ }^{35}$ Tengku Hasan M. di Tiro, "Speech delivered before the $43^{\text {nd }}$ UN Sub-Commission and Protection of Minorities", Switzerland: The United Nations, August 23th, 1991.

${ }^{36}$ Ibid. See also, "Speech delivered before the $48^{\text {th }}$ Session", Switzerland: The United Nations, January $29^{\text {th }}, 1992$.

${ }^{37}$ Tapol Bulletin, "Aceh Resolution at the UN", 1993, London: British Campaign for Human Rights, October report no: 119. See also. The United Nations, "UN Concern with Indonesia Grow", Switzerland: United Nations, October report no: 125, 1994.

* Washington Post, "Indonesia General Apologizes; Defence Chief Seeks Pardon in Province, Site of Rights Abuses", Washington D.C.: August 8th, 1998.

"Estafeta, "Aceh Conference Hell in New York", New York: P.O. Box 1182. p. 8.

"Agence France Presse, "Indonesia Leaves Troubled Aceh, Certain of Military Atrocities", Paris: August 23th, 1998.

"Asia Pulse, "Indonesian Government Questions Report on Aceh Killings", August 27th, 1998.

${ }^{2}$ Moid.

"Christim Science Monitor, "Despite Abuses, These Indonesians Want L'nity". September 1st, 1998.

"Deutsche Presse-Agentur, "Military Releases Death Toll in Aceh Operation". September 5 th, 1998. 
${ }^{45}$ Estafetta, "Aceh Conference Hall in New York", p. 11.

to Tapol Bulletin, "Army Brutality Reigns Supreme in Aceh", London: The Indonesian Human Right Campaign, report no: 151, pp. 12-13.

47 Ibid., p. 11.

4\$ Ibid., p. 12.

${ }^{47}$ The Sun, July $17^{\text {th }}, 1999$.

${ }^{50}$ Tapol Bulletin, report no.119, October, 1993.

${ }^{51}$ FEER, August $6^{\text {th }}, 1998$.

${ }^{52}$ Far Eastern Economic Review, Hongkong: May 13th, 1999, p. 28-30.

${ }_{53}$ Ibid.

${ }^{54}$ Ibid.

${ }^{55}$ Tapol Bulletin, report May 7th, 1999.

${ }^{56}$ Ibid.

${ }^{57}$ Ibid.

${ }^{58}$ WASPADA, Medan: July 2nd, 1999. 